mgr Lukasz KIELAN

Wydział Zarządzania, Uniwersytet Lódzki

e-mail: kielan82@onet.eu

ORCID: 0000-0002-9181-0812

mgr Maciej Władysław PEŁCZEWSKI

Wydział Zarządzania, Uniwersytet Lódzki

e-mail: maciej.pelczewski@interia.pl

ORCID: 0000-0002-9967-7999

DOI: $10.15290 / \mathrm{OES} .2021 .04 .106 .09$

\title{
PROBLEM AGENCJI Z PERSPEKTYWY MENEDŻERA SPOZA RODZINY NA PRZYKLADZIE WYBRANEJ FIRMY RODZINNEJ ${ }^{1}$
}

\begin{abstract}
Streszczenie
Cel - Celem artykułu jest przedstawienie problemu agencji z perspektywy menedżera zarządzającego firmą rodzinną. Autorzy przedstawili rys teoretyczny, następnie przeanalizowali wyniki badań przeprowadzonych na wybranym przedsiębiorstwie rodzinnym i przedstawili model zarządzania problemem.

Metoda badań - W opracowaniu zastosowano metodę monograficzna, studium jednokrotnego przypadku oraz analizę literatury.

Wyniki - Przedstawienie perspektywy menedżera spoza rodziny, zarządzającego firmą rodzinna, a także rozwiązań minimalizujących konflikty na linii agent - pryncypał.

Oryginalnosí / wartosíc / implikacje / rekomendacje - W artykule zaprezentowano szereg rozwiązań, których wdrożenie zapewni ochronę własności rodziny przed oportunistycznym działaniem menedżera z zewnątrz.
\end{abstract}

Słowa kluczowe: teoria agencji, firma rodzinna, konflikt

\section{Summary}

Purpose - The purpose of the article is to present the problem of an agency from the perspective of a manager managing a family business. The authors will present a theoretical outline, then analyse the results of research carried out on a selected family enterprise and present a problem management model.

Research method - The study uses classical research methods, such as the analysis of the literature on the subject, as well as a single-case study.

Result - Presenting the perspective of a manager, from outside the family, managing a family business, as well as solutions minimizing the conflict between agent and principal.

Conclusions - In this case, the authors presented the results of research in a company in which part of the management is assigned to the manager. In the light of the already known research of companies in Poland, there are very few such examples, which was a research gap that the authors wanted to fill.

1 Artykuł wpłynął 9 marca 2021 r., zaakceptowano 26 sierpnia 2021 r. 
Keywords: agency theory, family businesses, agent-principal conflict

JEL Classification: K10, M31

\section{Wprowadzenie}

Autorzy artykułu podjęli się przedstawienia problemów agencji z perspektywy menedżera w wybranej firmie rodzinnej. Dobór takiej tematyki badań był podyktowany chęcia poszerzenia wiedzy na temat firm rodzinnych, ale przede wszystkim zaprezentowania jej z perspektywy menedżera. Większość firm rodzinnych ma obawy przed przekazaniem zarządzania osobie niezwiązanej z firma, stąd mała liczba przykładów firm polskich, opisywanych w literaturze polskiej, traktującej o tym problemie.

W literaturze funkcjonuje kilkadziesiąt teorii przedsiębiorstwa, których celem jest zdefiniowanie firmy, wyznaczenie jej granic, scharakteryzowanie relacji wewnętrznych, określenie interakcji z bliższymi i dalszymi interesariuszami oraz ich ról i znaczenia $\mathrm{w}$ procesie zarządzania. W przypadku poznania specyfiki zarządzania firm rodzinnych największe zastosowanie znajdują teorie wywodzące się z nurtu nowej ekonomii instytucjonalnej, tj. teoria kosztów transakcyjnych, teoria agencji wraz z teorią służebności, a także teoria praw własności. Z perspektywy firm rodzinnych warto również uwzględnić teorię zasobową [Zajkowski, 2018, s. 91].

Zdaniem niektórych uczonych teoria agencji oraz teoria służebności mogą stanowić punkt wyjścia do zrozumienia głównych problemów, z którymi zmagają się firmy rodzinne. K. Madison, D.T. Holt, F.W. Kellermanns, A.L. Ranft [2016, s. 65-93] podjęli się przeglądu literatury poruszającej zagadnienia znaczenia teorii agencji oraz teorii stewarda $\mathrm{w}$ zrozumieniu firm rodzinnych. Porównali te dwie teorie w odniesieniu do przedsiębiorczości rodzinnej i wyróżnili składowe różniące, jak np. typ człowieka, zachowania, efekty oraz ład korporacyjny [Madison i in., 2016, s. 65-93; Wierzbicka, Strumiłło, 2018, s. 247].

Należy mieć na uwadze, że problem agencji może dotyczyć każdej organizacji, w której występuje podział pracy oraz rozbieżność celów interesariuszy. Naukowcy prezentują dwa podejścia do teorii agencji: pozytywne i normatywne. W nurcie pozytywnym analizujemy związek struktury własności, systemu zarządzania, wynagradzania menedżerów z siłą konfliktów między interesariuszami oraz wzrostem problemów o charakterze agencyjnym. Na każdej z tych płaszczyzn powstają konflikty o charakterze agencyjnym. W nurcie normatywnym analizie poddawane są czynniki wpływające na zawieranie umów pomiędzy stronami konfliktu. W centralnym punkcie jest zagadnienie ryzyka oraz formułowanie umów optymalnych, godzących w interesy obydwu stron [Rychłowska-Musiał, 2011, s. 12; Sadkowska, 2016].

Największym wyzwaniem, czekającym polskie firmy rodzinne w najbliższych latach, jest proces zmiany pokoleniowej i przekazanie firmy następcom. 84,1\% firm rodzinnych znajduje się w posiadaniu pierwszego pokolenia, zaś $57 \%$ planuje sukcesję w ciągu najbliższych 5 lat [jeżak i in., 2014, s. 48-49]. Niepokojące jest 
również to, że $68,4 \%$ badanych firm nie miała jeszcze sprecyzowanych planów co do sukcesji, a jedynie w 5,5\% firm potencjalni następcy byli przygotowywani do przejęcia firmy [Lewandowska i in., 2017, s. 27]. W 2013 r. Instytut Firm Rodzinnych przeprowadził badanie wśród potencjalnych następców firm rodzinnych, które pokazało, że jedynie $6,3 \%$ badanych wyraziło zainteresowanie przejęciem rodzinnego biznesu [Lewandowska, Tylczyński, 2014, s. 17-19]. Sukcesja zewnętrzna, polegająca najczęściej na zatrudnieniu menedżera spoza rodziny i skupieniu się jedynie na monitorowaniu osiagnięć firmy z pozycji członka rady nadzorczej, zdobywa na zachodzie coraz większa popularność. Stąd, naszym zdaniem, zasadne jest skupienie się na przedsiębiorstwach zarządzanych przez menedżerów spoza rodziny i zbadanie, w jaki sposób właściciele dążą do zapewnienia realizacji celów firmy i rodziny.

Autorzy artykułu skupili się na przedstawieniu wyników badań, które pokazują, jak w perspektywie menedżera spoza rodziny wygląda zarządzanie w firmie rodzinnej. Celem artykułu jest zidentyfikowanie narzędzi i rozwiązań, stosowanych przez właścicieli firm rodzinnych oraz menedżerów spoza rodziny, ograniczających ryzyko wystapienia konfliktów o charakterze agencyjnym. Autorzy przedstawili także szersza perspektywę na przykładzie wybranej firmy rodzinnej.

\section{Teoria agencji - ujęcie teoretyczne}

Teoria agencji opisuje związek między dwoma stronami: dyrektorem i agent-menedżerem [Eisenhardt, 1988; Jensen, Meckling, 1976; Stavrou, 1999].

Zaczyna się ona przy założeniu, że ludzie są skłonni do działania oportunistycznego [Barney, Hesterly, 2012]. W tym przypadku można spotkać się z dwoma sytuacjami, które będą analizowane pod kątem badawczym. Pierwszą z nich jest ta, w której firmą zarządza właściciel, a drugą, w której zarządza zatrudniony z zewnątrz menedżer.

Teoretycy agencji sugeruja, że podjęcie ryzykownych ruchów przez firmę zależy od tego, kto zarządza i czy jest jednocześnie właścicielem [Fama, Jensen, 1983; Jensen, Meckling, 1976]. Bardzo często, jak pokazują badania, w prywatnych firmach rodzinnych prezes ma kontrolę strategiczną [Harris, Ogbonna, 2007]. Oznacza to, że może znacząco wpłynąć na decyzje finansowe firmy, podejmując ryzyko bądź zarządzając bardziej zachowawczo.

Niektórzy badacze sugerują, że „teoria agencji oferuje bogate i owocne ramy odniesienia, dzięki którym można zbadać szczególne problemy firm rodzinnych" [Chrisman i in., 2004, s. 351]. Badacze, zarówno w XX wieku, jak i ówcześnie, starają się znacznie rozszerzyć kontekst badania i analizować coraz nowsze aspekty dotyczące teorii agencji.

Teoria agencji może mieć także charakter nieempiryczno-matematyczny. Wówczas natychmiastowym celem jest sporządzenie optymalnej umowy pomiędzy zleceniodawcą a agentem w zależności od poziomu niepewności niechęci stron do 
ryzyka i zatrudnienia, a także na podstawie dostępnych dla obu stron informacji [Eisenhardt, 1988].

Z drugiej strony, K.M. Eisenhardt [1988] mówi także o pozytywnej teorii agencji, o znacznie bardziej empirycznym i niematematycznym charakterze, która analizuje problemy agencji i przedstawia szereg mechanizmów ich zarządzania. W swoich badaniach dotyczących pozytywnej teorii agencji podaje również dwa mechanizmy zarządzania, które moga przyczynić się do efektywnego ograniczenia postaw oportunistycznych agenta.

Pierwszym $z$ nich jest zawieranie umów wyłącznie na podstawie satysfakcjonujących wyników. Sprawdza się, gdy koszty kontrolowania agenta są bardzo wysokie. Wówczas podpisanie umowy następuje tylko wtedy, kiedy efekty pracy agenta sa zadowalające, a cele przed nim postawione zostały spełnione. Drugim sposobem może być opracowanie odpowiednich systemów informacyjnych do monitorowania wyników, a także wprowadzenie narzędzi kontroli, które uświadomią agentowi, że nie da się oszukać właściciela [Alcalá Villarreal, 2011].

System własności gwarantuje prawo do nadzoru i kontroli nad kapitałem powierzonym przez akcjonariuszy/właścicieli. Potrzeba nadzoru wynika z rozbieżności interesów między akcjonariuszami i właścicielami a kadrą zarządzającą przedsiębiorstwa. Ten rodzaj nadzoru określany jest pojęciem corporate governance, w polskiej literaturze tłumaczy się ten termin jako nadzór nad działalnością spółki, nadzór korporacyjny czy też nadzór właścicielski [Bogacz-Miętka, 2011, s. 18-19].

Teoria agencji, a przede wszystkim tzw. relacje agencji, pozwalają wyjaśnić istotę nadzoru właścicielskiego. Cytowani wcześniej M.C. Jensen i W.H. Meckling [1976, s. 308] zdefiniowali relację agencyjną jako umowę, na mocy której jedna lub więcej osób (pryncypał) angażuje inną osobę (agenta) do wykonania pewnych usług w ich imieniu, delegując uprawnienia i środki decyzyjne. Delegując uprawnienia decyzyjne na rzecz agenta, pryncypał oczekuje wykonania obowiązków zgodnie z jego interesem [Bogacz-Miętka, 2011, s. 19-20].

Pomimo wysokiego stopnia niepewności dotyczącej wielu zmiennych, agent i zleceniodawca muszą być w stanie przewidzieć jak najwięcej niespodziewanych okoliczności i tak spisać umowę, aby tworzyła solidne struktury, które rozwiążą potencjalne konflikty i, co szczególnie istotne, pozwolą wyeliminować je w przyszłości [Ricart, 1991].

Na podstawie przeglądu literatury oraz własnych obserwacji autorzy sformułowali następujące pytanie badawcze: Jakie instrumenty wykorzystują właściciele firm rodzinnych oraz menedżerowie spoza rodziny w celu ograniczenia ryzyka wystapienia konfliktów o charakterze agencyjnym?

\section{Problemy o charakterze agencyjnym. Pryncypał i agent}

Zgodnie z teorią agencji wysoka stawka jedynego właściciela-menedżera powoduje niską dywersyfikację jego finansów, co prowadzi do niskiej preferencji dla nowych projektów z niepewnymi zwrotami [Jensen, Meckling, 1976; Sharma i in., 2003]. 
Problemy o charakterze agencyjnym pojawiają się z chwilą wystąienia relacji agencji. Mogą one dotyczyć:

- $\quad$ sprzeczności celów pryncypała i agenta oraz sytuacji, kiedy pryncypał, z uwagi na trudności lub wysokie koszty, nie może sprawdzić działań agenta,

- odmiennego podejścia do ryzyka.

Następstwem oddzielenia własności od zarządzania są często problemy o charakterze agencyjnym. Właściciele przedsiębiorstwa zostają pozbawieni dostępu do informacji oraz możliwości wpływu na wykorzystanie przez zarządzających zainwestowanego kapitału [Koładkiewicz, 1999, s. 43]. Zachowania menedżerów moga przejawiać się w postaci inwestowania środków finansowych spółki w nieefektywne projekty, dążenia do osiagania nadmiernych korzyści pozapłacowych (wysokie wydatki reprezentacyjne, luksusowe samochody, kosztowne podróże itp.) aż po wyprzedaż majątku spółki po zaniżonych cenach znajomym lub rodzinie i zakładanie własnych firm przy wykorzystaniu własności intelektualnej spółki i kontaktów [Jeżak, 2012, s. 790-791]. Asymetria informacji przejawia się między innymi w występowaniu między stronami ukrytych:

- informacji, gdy agent jest w posiadaniu wiedzy niedostępnej dla osób trzecich,

- działań agenta, tzn. takich, których nie jest w stanie zaobserwować pryncypał [Rychłowska-Musiał, 2011, s. 12].

W pierwszym przypadku możemy mieć do czynienia z tzw. selekcją negatywna, która polega na tym, że w wyniku asymetrii informacji lepiej poinformowani uczestnicy rynku moga wypierać konkurentów, oferując dobra „gorszej” jakości. Drugie zjawisko wynikające $z$ asymetrii informacji określane jest mianem ryzyka (hazardu) moralnego lub pokusy nadużycia [Rychłowska-Musiał, 2011, s. 12]. Problem agencji pojawia się wtedy, kiedy nastawienie do ryzyka jest różne u każdej ze stron. Agent, niebędący właścicielem firmy, może podejmować ryzykowne decyzje, których konsekwencje poniesie wyłącznie pryncypał w przypadku popełnienia błędu. Rozwiązaniem tego problemu może być znalezienie kompromisu pomiędzy czynnikami motywującymi agenta a stopniem ryzyka, jakie jest w stanie podjąć [Rychłowska-Musiał, 2011, s. 12].

Kolejnym problemem o charakterze agencyjnym, który pojawia się w organizacjach, jest brak możliwości spisania kontraktu pomiędzy pryncypałem a agentem, obejmującego wszystkie możliwe do przewidzenia okoliczności. Rozwiązać ten problem można na dwa sposoby. Po pierwsze, zawierając kontrakt oparty na wynikach, czyli uzależnienie dochodów agenta od osiaganych przez firmę wyników finansowych. Taki kontrakt może być uzupełniony o dodatkowe elementy motywujące, jak np. udostępnienie części akcji, oferowanie opcji na zakup po cenach preferencyjnych, określenie warunków rozwiązania umowy i zapisanie kwoty rekompensaty. Po drugie, ograniczając zjawiska asymetrii informacji poprzez wykorzystanie informacji z rynku kapitałowego, przedsiębiorstw czy rynku menedżerów [jeżak, 2012, s. 791-792]. Właściciele firm rodzinnych niechętnie dzielą się własnością, dlatego też można założyć, że oferowanie udziałów w firmie nie znajdzie zastosowania w tych podmiotach. $Z$ drugiej strony, dzięki zaangażowaniu członków rodziny 
w działania firmy niezwiązane z zarządzaniem właściciel ma możliwość monitorowania działań agenta i szybszego reagowania w przypadku wykrycia nieuczciwych lub błędnych działań menedżera spoza rodziny.

Konflikty o charakterze agencyjnym w przedsiębiorstwie pojawiają się najczęściej przy redystrybucji wolnych środków pieniężnych w obliczu trudności finansowych oraz w strukturze kapitału. Uczeni dowiedli, że menedżerowie zawsze będą dążyli do przeznaczania wolnych środków na inwestycje kosztem wypłaty dywidendy, a także do zachowania trwałości przedsiębiorstwa, mimo że bardziej opłacalne dla właścicieli byłyby sprzedaż oraz pojawienie się obcego kapitału w przedsiębiorstwie. Wypłata dywidendy lub sprzedaż udziałów zmniejsza środki dostępne dla menedżerów, a dodatkowo wprowadza nowe instrumenty kontroli [Rychłowska-Musiał, 2011, s. 26].

Tego typu konfliktom można zapobiegać, wypracowując odpowiednie mechanizmy, które pozwolą zarządzać przedsiębiorstwem zgodnie $\mathrm{z}$ interesem właścicieli. W literaturze można znaleźć mechanizmy: zewnętrzne, wewnętrzne i regulacyjne [Bogacz-Miętka, 2011, s. 42]. Jeśli zewnętrzne i wewnętrzne mechanizmy oraz regulacje przyczyniają się do realizacji celów spółki - tworzenia wartości dla wszystkich interesariuszy, to wtedy możemy mówić o efektywnym nadzorze korporacyjnym.

\section{Problem agencji w firmach rodzinnych}

Firmy rodzinne są specyficznym podmiotem, który można przedstawić jako system składający się z trzech oddzielnych podsystemów: rodzinnego, biznesowego i własności, z których każdy ma określone granice, zasady zachowań oraz cele. W firmie rodzinnej możemy spotkać: właścicieli i ich spadkobierców pracujących i posiadających udziały, członków rodziny, którzy posiadaja udziały, ale nie pracuja w firmie, członków rodziny pracujących w firmie, ale nie posiadających udziałów, osoby niebędące członkami rodziny, ale posiadające udział we własności i pracujące w firmie [Jeżak i in., 2004, s. 21-22]. Tak skomplikowana struktura firmy rodzinnej prowadzi do licznych konfliktów i sprzeczności, których rozwiązanie jest po stronie właścicieli i zarządzających.

Badając firmy rodzinne, początkowo nie dostrzegano problemów o charakterze agencyjnym $z$ uwagi na skupienie własności i zarządzania w rękach rodziny, której interesy są zbieżne i nie występuje potrzeba monitorowania realizacji celów.

Do konfliktów o charakterze agencyjnym w firmie rodzinnej dochodzi najczęściej na linii menedżer zewnętrzny a:

- właściciele (członkowie rodziny),

- menedżerowie z rodziny,

- pracownicy będący członkami rodziny,

- członkowie rodziny niepełniący żadnych funkcji w firmie [Zajkowski, 2018, s. 152].

$\mathrm{Z}$ analizy etapów życia przedsiębiorstwa, w tym przedsiębiorstwa rodzinnego, wynika, że najczęściej do konfliktów o charakterze agencyjnym dochodzi na etapie „kie- 
rowania" według modelu zaproponowanego przez L.E. Greiner'a [1997, s. 397-409]. Model zakłada 6 etapów rozwoju organizacji i składa się z faz ewolucji i rewolucji. Autor zakłada, że na każdym etapie rozwoju przedsiębiorstwa dochodzi do określonego kryzysu. Etap „kierowania” charakteryzują współzawodnictwo i konflikty między menedżerami dążącymi do zaspokajania własnych potrzeb i uzyskiwania coraz większych profitów [Zajkowski, 2018, s. 58-61].

Inne koncepcje odnoszące się do cyklu życia przedsiębiorstwa nie są tak rozbudowane jak powyższa. Dla przykładu koncepcja autorstwa K.E. Gersick'a i innych [1997, s. 17] zakłada 3 fazy rozwoju przedsiębiorstwa rodzinnego, z których najbardziej nacechowana konfliktami o charakterze agencyjnym jest faza środkowa, związana z ekspansją bądź stabilizacją. Wtedy to mają miejsce zmiany o charakterze właścicielskim i zarządzającym. W innym modelu okres ten odpowiada profesjonalizacji w zakresie zarządzania. Jedyny właściciel lub właściciele powoli dopuszczają do firmy inne osoby, członków rodziny lub menedżerów z zewnątrz [Zajkowski, 2018, s. 63].

Jeden z najbardziej uznanych ekspertów od firm rodzinnych - John Word zaproponował odmienny model ukierunkowany na struktury własnościowe. Model zakładał 3 etapy: etap założyciela, partnerstwo rodzeństwa oraz konfederację kuzynów. Konflikty będą najbardziej widoczne w 2 i 3 fazie, kiedy przedsiębiorstwo będzie się rozrastało wraz z powiększaniem się rodziny [Leach, 2017, s. 316; Shaker, Astrachan, 1996, s. 109].

Problemy o charakterze agencyjnym dotykają firmę wraz z jej rozwojem i wzrostem, kiedy właściciele nie są w stanie samodzielnie zarządzać firmą i decydują się na zatrudnienie zewnętrznych menedżerów. Inna koncepcja, odnosząca się stricte do firm rodzinnych, zakłada 4 etapy rozwoju przedsiębiorstwa. Z punktu widzenia konfliktów o charakterze agencyjnym, najważniejsze są etapy 3 i 4, obejmujące odpowiednio profesjonalizację zarządzania i instytucjonalizację [Leach, 2017, s. 64].

Teoria agencji jest punktem wyjścia do omówienia mechanizmów nadzoru korporacyjnego, w tym w przedsiębiorstwach rodzinnych. A. Surdej i K. Wach [2010, s. 35] definiuja dwa typy problemów o charakterze agencyjnym, występujące w firmach rodzinnych. W przypadku młodych firm zarządzanych przez pierwsze pokolenie, w których najczęściej właściciel odgrywa jednocześnie rolę zarządzającego, nie występuje konflikt interesów pomiędzy właścicielem a zarządzającym (problem agencji typu I). Właściciel, odgrywając rolę menedżera, nie będzie działał na szkodę firmy poprzez realizację niedochodowych inwestycji czy zawyżanie płac. Warto zaznaczyć, że przedsiębiorcy zarządzający jednocześnie firmą podchodzą do swoich biznesów bardzo emocjonalnie, ich motywacja do pracy jest wyższa niż w przypadku menedżerów nienależących do rodziny.

Jeśli jednak właścicielem firmy nie jest jedynie rodzina, może pojawić się konflikt agencji typu II. Duży udziałowiec, kontrolujący firmę, może wyprowadzać zyski ze spółki kosztem mniejszych udziałowców. Objawiać się to może również poprzez tzw. rozwadnianie zysku, polegające na wypłacie wysokich wynagrodzeń, zatrudnianiu członków rodziny, realizacji nieefektywnych kontraktów z innymi spółkami należącymi do rodziny [Surdej, Wach, 2010, s. 35-36]. 
Minimalizacji zagrożeń występowania konfliktów o charakterze agencyjnym sprzyjać mogą wdrożone mechanizmy zapewniające nadzór nad firma, a tym samym kontrolę działań menedżerów.

Postępująca profesjonalizacja zarządzania w polskich firmach rodzinnych sprawia, że zrozumienie problemów o charakterze agencyjnym jest niezwykle ważne dla właścicieli firm rodzinnych. Dla młodego pokolenia właścicieli firm rodzinnych profesjonalizacja zarządzania jest jednym z priorytetów i czynników gwarantujących rozwój firmy. $\mathrm{Z}$ raportu $\mathrm{O}$ biz̨nesie rodrinnym glosem sukcesoróm. Różne ścię̌ki, te same priorytety wynika, że oprócz profesjonalizacji młodzi właściciele stawiają na dywersyfikację, innowację i transformację cyfrową. Wraz ze wzrostem wartości przedsiębiorstwa pojawia się potrzeba rozszerzenia kadry zarządczej o menedżerów spoza rodziny. W raporcie PWC [Great expectations ..., 2016] zwrócono uwagę, że w części firm rodzinnych następuje zmiana z family business na business family, czyli sytuacja, w której rodzina utrzymuje własność i zasiada w radzie nadzorczej, oddając zarządzanie firmą menedżerom z zewnątrz [Beelen, Whitmore, 2018, s. 1-32]. Trzeba jednocześnie przyznać, że takie rozwiązanie niesie za sobą również pewne niebezpieczeństwo, jeśli członkowie rady nadzorczej nie będa posiadali odpowiednich kwalifikacji i umiejętności.

\section{Teoria agencji na przykładzie firmy rodzinnej-wyniki badań}

Wybór jednostki do badania był celowy - jeden z autorów artykułu współpracował z firma przy realizacji projektu doradczego, znał się osobiście z prezesem zarządu. Badane przedsiębiorstwo jest średnią firmą założoną w 1989 r., zatrudniająca 80 pracowników. Jej działalność skupia się na trzech obszarach, z czego jeden jest wiodący i generuje $80 \%$ przychodów. Firma działa w branży przetwórstwa tworzyw sztucznych i jej produkty mają zastosowanie w każdym gospodarstwie domowym. Jest to wysoce innowacyjne przedsiębiorstwo, aktywnie współpracuje z jednostkami badawczo-rozwojowymi, produkty powstaja na licencji firmy zagranicznej, z którą firma współpracuje od lat. Jej produkty są dostarczane zarówno na rynek krajowy, jak i na rynki zagraniczne (Niemcy, Holandia, Włochy, Stany Zjednoczone, Rosja, Ukraina, Białoruś i Litwa). Model biznesowy zakłada sprzedaż hurtową i detaliczna.

Teoria agencji odnosi się do bardzo wrażliwych tematów, m.in. wynagrodzenia, oceny pracowniczej, dlatego też nie uzyskałem zgody na upublicznienie nazwy firmy. Drugim powodem, dla którego autorzy zdecydowali się wybrać właśnie tę firmę, jest powierzenie zarządzania osobom spoza rodziny (rysunek 1). Jest to rzadko spotykana sytuacja w polskich firmach rodzinnych, tym bardziej że właściciel ma dzieci, które w niej pracuja. Kwestia kontroli nad przedsiębiorstwem jest jednym z priorytetów dla firm rodzinnych i niechętnie właściciele dopuszczają do zarządzania osoby z zewnątrz. Takie zachowawcze podejście może wynikać z obawy przed utratą kontroli nad informacjami stanowiącymi tajemnicę przedsiębiorstwa oraz własnością intelektualną. 
W celu zobrazowania problemów o charakterze agencyjnym oraz mechanizmów służących do łagodzenia konfliktów na tym polu wykorzystano jakościowe studium przypadku - przedsiębiorstwo rodzinne zarządzane przez menedżerów zewnętrznych. Pojęcie przypadku definiujemy jako „pojedynczy obiekt badawczy, rozpoznawany ze względu na określony cel, usytuowany w konkretnym miejscu i czasie, z uwzględnieniem właściwych mu okoliczności" [Czakon, 2015, s. 190]. Wykorzystanie metody jakościowej pozwala na bardziej precyzyjne uchwycenie specyfiki przedsiębiorstwa rodzinnego i uwzględnienie wpływu zmiennych niemierzalnych lub trudno mierzalnych na zarządzanie firmą. Studium przypadku jako metoda badawcza jest odpowiednia do badania organizacji oraz procesów zachodzących wewnątrz [Matejun, 2011, s. 203]. Zastosowanie studium przypadku daje nam możliwość ujęcia badanego zjawiska w całościowej perspektywie, pozwala uzyskać głębsze i pełniejsze zrozumienie. Przedsiębiorstwo rodzinne jest specyficznym podmiotem i poprzez szerokie ujęcie zjawiska mamy możliwość poznania struktury oraz relacji panujących w przedsiębiorstwie, ze szczególnym uwzględnieniem stosunków między właścicielem a menedżerem spoza rodziny [Babbie, 2004, s. 309-320].

\section{STRUKTURA ZARZĄDZANIA W BADANYM PRZEDSIĘBIORSTWIE RODZINNYM}

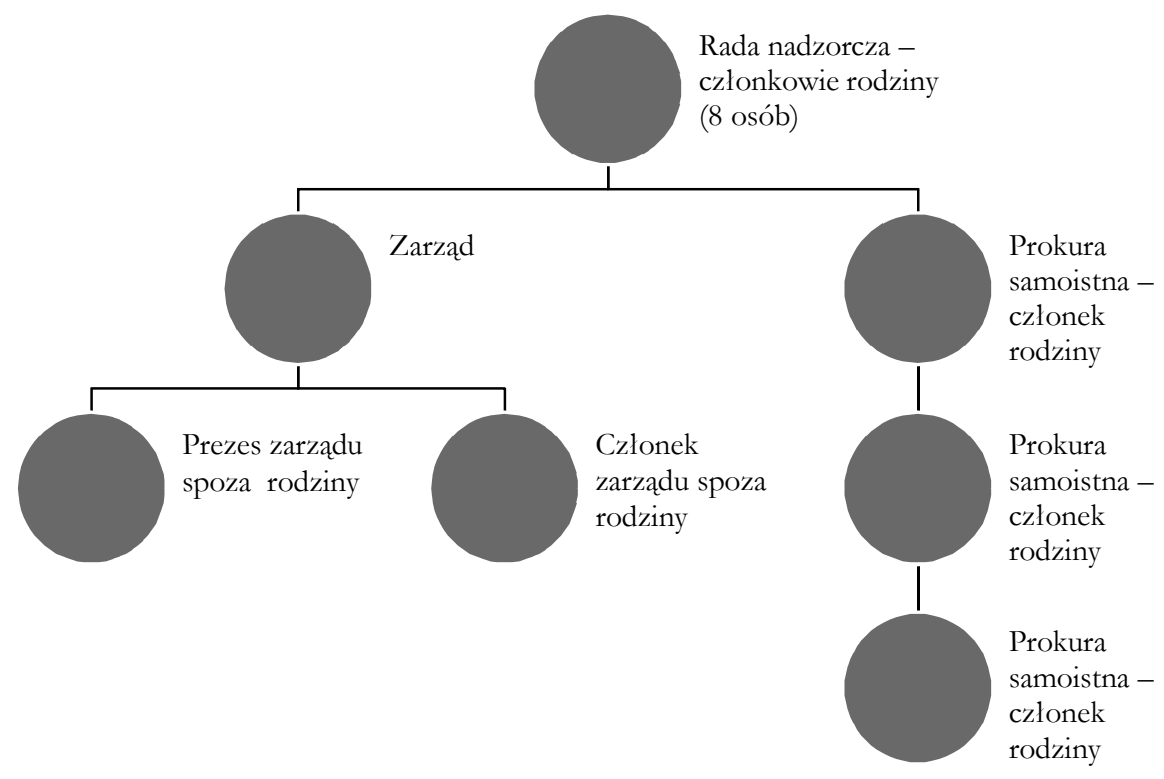

Źródło: opracowanie własne na podstawie wpisu do KRS i informacji uzyskanych w firmie. 
W procesie badawczym opartym na metodzie studium przypadku wykorzystujemy szereg technik i narzędzi do zebrania materiału do analizy [Matejun, 2011, s. 205]. Bazę empiryczną studium przypadku w prezentowanym artykule stanowi pogłębiony wywiad $z$ prezesem zarządu - menedżerem spoza rodziny - oraz analiza dokumentów, wpis do KRS, strategia rozwoju firmy. Triangulacja opiera się na zastosowaniu różnych źródeł danych, zaś wywiad przeprowadzony z menedżerem firmy miał charakter ustrukturyzowany. Pytania dotyczyły sposobów wynagradzania członków zarządu, kanałów komunikacji pomiędzy zarządem a właścicielem, mechanizmów zatwierdzania sprawozdania finansowego i podejmowania strategicznych decyzji w spółce oraz relacji pomiędzy członkami zarządu a właścicielem $\mathrm{i}$ innymi pracownikami przedsiębiorstwa pochodzącymi z rodziny właścicielskiej.

Firma stanowi dobry przykład dla innych podmiotów, nie tylko rodzinnych, w zakresie organizacji i zarządzania. Posiada odpowiednie struktury organizacyjne, z jasnym podziałem odpowiedzialności za realizację określonych działań, struktury zarządcze w postaci zarządu oraz rady nadzorczej i spisaną strategię rozwoju, co również nie jest często spotykane w polskich firmach.

Struktura właścicielska przedstawia się następująco:

- $\quad$ ojciec posiada $80 \%$ udziałów,

- $\quad$ syn posiada $20 \%$ udziałów.

Firma obecnie przechodzi zmianę międzypokoleniowa. Dzieci właściciela pracuja w niej, zdobywają doświadczenie, a jeden z synów otrzymał 20\% udziałów we własności przedsiębiorstwa.

Do najskuteczniejszych narzędzi zapewniających kontrolę działań agenta przez pryncypała należą:

- zapewnienie dostępu do informacji poprzez powołanie organu nadzorczego oraz wdrożenie procedur nadzoru,

- $\quad$ wynagrodzenie agenta uzależnione od wyników firmy,

- partycypacja menedżera we własności firmy.

W przedstawionej firmie rodzinnej dwuosobowy zarząd odpowiedzialny za kierowanie firmą wywodzi się spoza rodziny. Oprócz zarządu wywodzącego się spoza rodziny kontrolę nad spółką sprawuje rada nadzorcza składająca się z 8 członków należących do rodziny. Rada nadzorcza odgrywa istotną rolę w dyscyplinowaniu kadry zarządzającej, zapewnia funkcjonowanie firmy zgodnie $\mathrm{z}$ interesami właścicieli, czyli maksymalizuje zyski oraz ogranicza koszty agencji [Jeżak, 2012, s. 792]. W firmie rodzinnej pracują również inni członkowie rodziny, zatrudnieni na stanowiskach kierowniczych. Należy zaznaczyć, że w przypadku firm rodzinnych głównym celem nie zawsze jest maksymalizacja zysku w krótkim czasie. Firmy rodzinne działają w długookresowej perspektywie czasowej i oprócz maksymalizacji zysku istotne jest również przestrzeganie wartości wyznawanych przez rodzinę właściciela. Dlatego też menedżerowie zatrudnieni w firmie powinni mieć świadomość tego, że dodatni wskaźnik NPV nie będzie jedynym kryterium decydującym o podjęciu decyzji o realizacji projektu. Tak liczna rada nadzorcza wywodząca się $\mathrm{z}$ rodziny właściciela nie zawsze będzie w stanie obiektywnie ocenić działania 
podejmowane przez kadrę zarządzająca, za to na pewno będzie stała na straży wartości wyznawanych przez rodzinę założycieli.

W przypadku opisywanej firmy wynagrodzenie menedżerów zatrudnionych w firmie wywodzących się spoza rodziny składa się z dwóch elementów: stałej podstawy oraz premii uzależnionej od wyników firmy. Jest to postępowanie zgodne z rekomendacjami naukowców.

Twórcy teorii agencji, M.C. Jensen i W.H. Meckling [1976, s. 309], wyodrębnili trzy rodzaje kosztów agencyjnych:

- koszty monitorowania i kontrolowania działań agenta ponoszone przez mocodawcę,

- $\quad$ koszty ponoszone przez agenta w celu realizacji interesów pryncypała,

- stratę rezydualną.

W opisywanej firmie wdrożono system wynagradzania oparty na uzyskiwanych wynikach, za których osiagnięcie są przyznawane premie. Niektórzy sugeruja, że właściwym rozwiązaniem motywującym działanie agenta do efektywnej pracy i realizacji zadań zleconych przez pryncypała może być partycypacja menedżera we własności firmy. Z pewnością wpłynęłaby na ograniczenie kosztów o charakterze agencyjnym i ograniczenie rozbieżności interesów, ale problem w tym, że, jak pisano wcześniej, firmy rodzinne niechętnie dzielą się władzą, a co dopiero własnością.

W firmie rodzinnej stosuje się praktykę systematycznych spotkań właścicieli z zarządem i wspólnego rozwiązywania pojawiających się problemów. Sprawozdania finansowe przygotowane przez zarząd firmy poddawane są badaniu przez biegłego rewidenta. Właściciele przedsiębiorstwa nałożyli ograniczenie na kadrę zarządzająca dotyczące zaciagania zobowiązań powyżej 25000 zł. Ograniczenie zostało zamieszczone we wpisie do Krajowego Rejestru Sądowego. Zobowiązania powyżej tej kwoty może zaciagać członek zarządu z prokurentem lub dwóch prokurentów działających samoistnie, czyli każdą taką transakcję musi zatwierdzić rodzina.

Strata rezydualna czy wyrażona wartościowa obniżona wartość spółki/firmy rodzinnej na skutek oportunistycznego, zachowawczego działania agenta jest niezwykle trudna do oszacowania. Z uwagi na zatrudnienie w firmie członków rodziny właściciel ma dużo większy dostęp do informacji na temat firmy, jej sytuacji ekonomicznej. Członkowie rodziny zatrudnieni w firmie ograniczaja zjawisko działania właściciela w asymetrii informacji. Pozwala to lepiej kontrolować firmę i szybciej reagować na zmiany.

\section{Podsumowanie}

W artykule przedstawiony został wpływ teorii agencji na zarządzanie w wybranej firmie rodzinnej, a także pokazana została perspektywa menedżera spoza rodziny. $\mathrm{W}$ związku $\mathrm{z}$ rosnąca profesjonalizacja zarządzania $\mathrm{w}$ polskich przedsiębiorstwach rodzinnych, przejawiającą się najczęściej w postaci zatrudniania wysoko wykwalifikowanych menedżerów pochodzących spoza rodziny, zrozumienie mechanizmów powstawania konfliktów o charakterze agencyjnym jest niezwykle ważne dla ich rozwoju. Następnym krokiem jest wdrożenie odpowiednich mechanizmów chroniących 
własność rodziny przed oportunistycznym działaniem menedżera. Z kolei menedżerowie zatrudnieni w firmach rodzinnych powinni mieć świadomość specyfiki działania takich podmiotów.

Artykul jest dobrym początkiem dalszej pracy naukowej, która może skupić się na stworzeniu uniwersalnych rekomendacji dla menedżera i właściciela w firmie rodzinnej. Rekomendacje mogą stanowić szereg rozwiązań, które będą minimalizować konflikty, a także doprowadzą do zmaksymalizowania zysków i zadowolenia właścicieli oraz menedżera.

\section{Literatura}

Alcalá Villarreal J.L., 2011, Las empresas de familia en la ciudad de Barranquilla y sus problemas de sucesión. Un enfoque desde la Teoría de la Agencia, "Artículo de Investigación Científica y Tecnológica", vol. 32(1), pp. 185-198.

Babbie E., 2004, Badania spoteczne w praktyce, WN PWN, Warszawa.

Barney J., Hesterly W.S., 2012, Strategic management and competitive advantage: concepts (4th ed.), Upper Saddle River, Pearson Education, New York.

Beelen M., Whitmore M., 2018, Nowe pokolenie firm rodzinnych. Eksploracja środowisk. bi₹nesonych, Raport Centrum Firm Rodzinnych Deloitte, https://www2.deloitte. $\mathrm{com} / \mathrm{pl} / \mathrm{pl} / \mathrm{pages} /$ firmy-rodzinne/articles/badanie-firm-rodzinnych-2018-next-gen. html [data dostępu: 16.08.2021].

Bogacz-Miętka O., 2011, Kompendium wiedsy o nadzorze i kontroli nad przedsięiorstwem, CeDeWu Sp. z o.o., Warszawa.

Chrisman J.J., Chua J.H., Litz R.A., 2004, Comparing the agency costs of family and nonfamily firms: conceptual issues and exploratory evidence, "Entrepreneurship Theory and Practice", vol. 28(4), pp. 335-354, DOI: 10.1111/j.1540-6520.2004.00049.

Czakon W., 2015, Podstany metodologii badań w naukach o zarzadzaniu, Wolter Kluwer S.A., Warszawa.

Eisenhadrdt K.M., 1988, Agency and institutional theory explanations: the case of retail sales compensation, "Academy of Management Journal", vol. 31(3), pp. 488-511, DOI: $10.2307 / 256457$.

Fama E.F., Jensen M.C., 1983, Separation of Ownership and Control, "Journal of Law and Economics", vol. 26, , No. 2, pp. 301-325.

Gersick K.E., McCollom M., Lansberg I., 1997, Generation to generation life cycles of the family business, Harvard Business School Press, Boston.

Great expectations - The Next Generation of Family Business Leadres, 2016, PWC, https:// www.pwc.com/gx/en/family-business-services/publications/assets/next-genreport.pdf [data dostępu: 16.08.2021].

Greiner L.E., 1997, Evolution and revolution as organizations grow: a company's past has clues for management that are critical to future success, "Family Business Review", vol. 10(4), pp. 397-409, DOI: 10.1111/j.1741-6248.1997.00397.x.

Harris L.C., Ogbonna E.O., 2007, Ownership and control in closely-held family-owned firms: an exploration of strategic and operational control, "British Journal of Management", vol. 18(1), pp. 5-26, DOI: 10.1111/j.1467-8551.2005.00471.x. 
Jensen M., Meckling W., 1976, Theory of the firm: Managerial, behavior, agency costs and ownership structure, "Journal of Financial Economics", vol. 3(4), pp. 305-360, DOI: 10.1016/0304-405X(76)90026-X.

Jeżak J., 2012, Ład wewnatrzkoorporacyjny w śmietle różnych teorii a wyzwania wspótczesności, „Finanse. Rynki Finansowe. Ubezpieczenia”, nr 51, s. 789-799.

Jeżak J., Kornecki J., Krajenta-Kopeć A., 2014, Skala i ekonomiczne znacz̧enie prz̧edsiebiorstw rodzinnych w Polsce (Raport z. badan empirycznych), [w:] Przedsiebiorstwa rodzinne w Polsce. Znaczenie ekonomiczne oraz strategiczne problemy rozwoju, Jeżak J. (red.), Wydawnictwo Uniwersytetu Łódzkiego, Łódź.

Jeżak J., Popczyk W., Winnicka-Popczyk A., 2004, Przedsiebiorstwo rodzinne. Funkejonowanie i rozwój, Difin, Warszawa.

Koładkiewicz I., 1999, Nadzór korporacyjny. Perspektywa miedzynarodowa, Polska Fundacja Promocji Kadr, Warszawa.

Leach P., 2017, Firmy rodzinne. Wszystko, co istotne, Wydawnictwo Studio EMKA, Warszawa.

Lewandowska A., Tylczyński Ł., 2014, Barometr sukcesyjny i prognozowane ścię̇ki kariery dzieci z firm rodzinnych, Instytut Biznesu Rodzinnego, Poznań.

Lewandowska A., Więcek-Janka E., Hadryś-Nowak A., Wojewoda M., Tylczyński M., 2017, Firma rodzinna to marka. Raport z badania przeprowadzonego w ramach projektu, „Statystyka firm rodzinnych”, nr projektu: 692654-18/12/2015, s. 1-34, DOI: 10. 13140/RG.2.2.27119.84644.

Madison K., Holt D.T., Kellermanns F.W., Ranft A.L., 2016, Viewing family firm behavior and governance through the lens of agency and stewardship theories, "Family Business Review”, vol. 29(1), pp. 65-93, DOI: 10.1177/0894486515594292.

Matejun M., 2011, Metoda studium praypadku w pracach badawczych mtodych naukowców z zakresu nauk o zarzqdzaniu, "Zeszyty Naukowe Uniwersytetu Szczecińskiego”, nr 666, „Problemy Zarządzania, Finansów i Marketingu”, nr 19, s. 203-213.

Ricart J.E., 1991, Una introducción a los modelos de agencia, [in:] Invitacióna la teoría económica, Marimon R., Calsamiglia, X. (eds.), Ariel, Barcelona.

Rychłowska-Musiał E., 2011, Miary kosztów agencji w spótkach akcyjnych, Wydawnictwo Uniwersytetu Ekonomicznego w Poznaniu, Poznań.

Sadkowska J., 2016, Ryzyko interesariuszy w zarzqdzaniu projektami na prayketadzie polskich firm rodzinnych, „Przedsiębiorczość i Zarządzanie”, t. XVII, z. 6, s. 303-317.

Shaker M.C, Astrachan J.H, 1996, Myths and realties: family businesses' contribution to the us economy - a framework for assessing family business statistic, "Family Business Review", vol. 9(2), pp. 107-119.

Sharma P., Chrisman J.J., Chua J.H., 2003, Succession planning as planned behavior: some empirical results, "Family Business Review", vol. 16(1), pp. 1-15, DOI: 10.1111/ j.1741-6248.2003.00001.x.

Stavrou E.T., 1999, Succession in family businesses: exploring the effects of demographic factors on offspring intentions to join and take over business, "Journal of Small Business Management", vol. 37(3), pp. 43-61.

Surdej A., Wach K., 2010, Przedsiębiorstwo rodzinne wobec wyzwań sukcesji, Difin, Warszawa. 
Wierzbicka B., Strumiłło J., 2018, Strategiczna Karta Wyników jako nośnik skutecznej aplikagi pomocy unijnej przęz firmy rodzৃinne, „Przedsiębiorczość i Zarządzanie: Firmy rodzinne - zarządzanie, rozwój, przedsiębiorczość", t. XIX, z. 7, cz. 1, s. 245-259.

Zajkowski R., 2018, Transfery władzy, własności i wartości w przedsiebiorstwach rodzinnych. Efekt drugiego pokolenia, Wydawnictwo C.H.Beck, Warszawa. 